\title{
Governance of heritage. Challenges of a community strengthen by its heritage
}

\author{
Gobernanza del patrimonio. Desafíos de una comunidad \\ impulsada por su patrimonio
}

\section{Resumen}

Natalia A. Juca Freire nataliajucaf@gmail.com

Investigadora independiente

Ecuador

Recibido: 31/Ene/2020 Aceptado: 14/Nov/2020 t $\mathrm{t}$ is crucial to review cases where heritage works as a means of empowering sustainable communities through participative governance and learn from these mechanisms. This paper aims to explore the lessons of participative governance in Agua Blanca, a small village located on the Ecuadorian coast, where heritage -archeological remains and dry tropical forests- constitutes the primary resource. The approach is qualitative, and the methods were archive analysis, observation, and open interviews. The villagers lead participative management that is based on equality of the access and distribution of resources. Through this vision, collective economic benefits from their heritage are achieved. Besides, the dwellers reinforce their identity through their cultural and natural heritage, which contributes to its preservation. Nevertheless, Agua Blanca faces challenges as the indifference of younger generations, territorial segregation, and the lack of relationships with government organisms. To confront these obstacles, it is recognized that the community is not a stable and permanent system but rather a set of difficulties that are overcome through inclusive governance mechanisms that evolve in the face of new necessities.

Keywords: heritage management; community; territory; participative governance; cultural landscape.

\section{Resumen:}

Es crucial revisar los casos en los que el patrimonio es un medio para empoderar comunidades sostenibles a través de la gobernanza participativa y aprender de estos mecanismos. Así, el objetivo es explorar las lecciones de la gobernanza participativa en Agua Blanca, un pequeño pueblo en la costa ecuatoriana, donde el patrimonio- restos arqueológicos y un bosque- constituyen el principal recurso. El enfoque es cualitativo y los métodos fueron el análisis de archivos, la observación y las entrevistas abiertas. La gestión participativa liderada por los pobladores se basa en la igualdad de acceso y distribución de recursos. Mediante esta visión, se logran beneficios económicos colectivos provenientes del patrimonio y los habitantes refuerzan su identidad a través de su patrimonio cultural y natural, contribuyendo a su preservación. Sin embargo, Agua Blanca enfrenta desafíos como la indiferencia de las generaciones jóvenes, la segregación territorial y la falta de relación con organismos gubernamentales. Frente a esto, se reconoce que la comunidad no es un sistema estable y permanente, sino una serie de dificultades que se superan mediante mecanismos de gobernanza inclusivos y que evolucionan ante nuevas necesidades.

Palabras clave: gestión del patrimonio; comunidad; territorio; gobernanza participativa; paisaje cultural. 


\section{Introduction}

Heritage ownership can be a door to land claims which can empower communities (Chirikure, Manyanga, Ndoro \& Pwiti, 2010) and can benefit their social and economic development. However, many communities are not aware of the importance of their heritage since there is a system where minorities (e.g., technical experts, government institutions) define values and meaning of a communities' heritage (Babic, 2015) as well as the proper ways of preserving it. It is imperative making communities take back of control over their heritage - their relationship to the past in the present - to decolonize the representation, interpretation, and maintenance of this heritage (Hollowell \& Nicholas, 2009). Therefore, it is crucial to empower local people, and articulate them in an open and democratic process of participative heritage governance (Mackay \& Johnston, 2010). Although many authors have recognized community-based heritage management as a positive process, it is still not widespread enough, and there is a lack of evaluations of the cases where this kind of practice has been developed, especially in Latin American countries.

Furthermore, within community-based heritage management is substantial the articulation with other organisms. Heritage management demands an understanding of all of the place-values so that these can be addressed and retained through appropriate policies and strategies. Research may play a crucial role within this process through the engagement of communities and the stimulate of interest and enthusiasm among communities by shedding light on some aspects (e.g. values, attachments, and perceptions) of their heritage (Chirikure et al., 2010). Therefore, researchers' potential to empower should not be underestimated. For instance, a community displaced by unjust policies can only make a claim to their heritage and legacy based on sound information and facts, rather than on political correctness (Chirikure et al., 2010). Nevertheless, the understanding of heritage values requires a combination of research and the involvement of associated people, especially those with firm connections with the place (Mackay \& Johnston, 2010).

In this context, this paper aims to explore the lessons of participative governance in the Agua Blanca community (achievements and challenges), considering the social, economic, and environmental structures under which heritage is handled.

\section{Background of the case study}

The Agua Blanca community is a small coastal town in Ecuador that has become a national reference due to its effective communitarian organization to preserve its territory conformed by archaeological remains and unique natural and cultural environment. These resources and the social-political organization of the villagers are based on how the participatory management has enabled them to practice community-based tourism for over 25 years. The participatory management was initially promoted by a group of researchers that changed the course of Agua Blanca to a favorable scenario. Since then, the internal processes (social, cultural, economic and environmental) of the place have been evolved in a very particular way, which has turned this village into a focus of interest for several foreign researchers. They have had very long periods of lodgment in the community, and their research and efforts have been a support for the development of the community.

Agua Blanca is located in the southwest of the Manab province, Puerto López Canton, within the Machalilla Park. Agua Blanca has a territory of 8,048 hectares and is made up of 80 families with approximately 300 inhabitants that are settled in three population centers: Centro, El Carmen, and Vueltas Largas (Fig. 1). The Machalilla Park has an area of 555,095 hectares, which includes zones of tropical dry forest, beaches and some islands (Endere \& Zulaica, 2015). Meanwhile, the archeological remains that lie under the settlement belong to the Valdidia, Machalilla, Chorrera, Bahia, Guangala and Manteña cultures that are of high relevance in the history of Ecuador due to their cultural and historical legacy. Sadly, the coastal area is usually left out of the heritage arena in Ecuador. Smith (2015) affirms that the colonial, tourist, and state discourses have built an Ecuadorian coast, perhaps without important roots to rescue, or with a heritage that lies only in the country's museums.

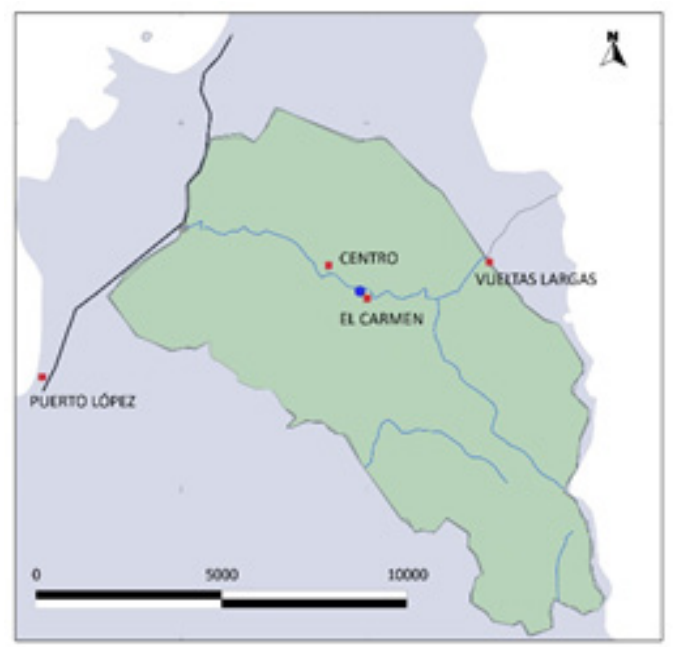

Figure 1: Map of Agua Blanca

Source: Luke Dallas 


\subsection{A brief history of Agua Blanca}

According to McEwan, Silva \& Hudson (2000), Agua Blanca has been continuously populated for approximately 5000 years. Its archeological ruins belong to the Manteña Culture (800 to 1532 AD), and it was an important network between señoríos such as Salongome, Salango, Cercapez, Tuzco, and Cancebí. Agua Blanca was an important ceremonial and social center until the sixteenth century, and declined with the arrival of the Spaniards; however, it is not known exactly what happened to the population due to its isolated location.

Although in the seventeenth century the place appears known as a "town of Indigenous," during the seventeenth to the twentieth centuries, the inhabitants of the site declared themselves as mestizos (Endere \& Zulaica, 2015), probably due to the physical and symbolic violence of the term Indian in Ecuador. According to Ruiz (2009), the territory was private until 1937, when the Communes Law appeared, which guaranteed that peasant or indigenous groups have control over their communal lands. The reforms of the Communes Law culminated in the late 1960s, and since 1964 the commune was established as a mere formality. However, in 1979 these lands became public property, constituting part of the natural reserves of Ecuador as the Machalilla National Park. When the park was constituted, there was much uncertainty about the continuity of the population, since its economic activities (charcoal commerce, extraction of wood and hunting) were opposite to the park's conservation policies (Endere \& Zulaica, 2015).

The persistence of this community was in danger, until 1978 when the Scottish archaeologist, Colin McEwan, arrived in the site and started to carry out excavations and investigations with the Ecuadorian María Isabel Silva. McEwan and Silva, leaders of the project, started a job not only as archeologists but their efforts intended to develop an integrated approach to culture, ecology and subsistence motivated by the conviction that communities play a vital role in protecting the environment and managing cultural resources (McEwan, Silva \& Hudson, 2006). They employed and trained the same villagers to excavate, create topographic maps, and process postexcavation material. Likewise, the main decisions were discussed and agreed with the community. Alliances and mediations between the community, the park, the national and foreign entities in the search for funding for the preservation of the community and its archaeological remains were consolidated (Endere \& Zulaica, 2015). The Machalilla National Park authorities understood that the villagers were capable of being the defenders of the park.

Finally, thanks to the funding from the British Embassy, the community-in cooperation with the architect Chris Hudson- a site museum was built and also considered as a cultural house. They used traditional techniques, local materials, and the construction work was collective. The objective was that the community could identify itself with the new building. The museum opened to the public in 1990. This last stage redirected the life of the community since it established as a touristic community. McEwan, Silva \& Hudson (2006) acknowledged that the process was not easy and there were several obstacles derived from ignorance, indifference, and hostility in front of a new way of work; but mainly from the lack of cultural policies for working and participative management. However, their efforts and the support from people and institutions made it possible to establish a community with the capacity for self-organization in order to improve their life quality. Eventually, the villagers no longer needed the mediation of externals for their management. The villagers became custodians of the natural environment and the archaeological remains. They improved their local economy, and above all, they gained empowerment to protect their territory. Currently, the Agua Blanca community receives more than 1000 visitors per year.

\section{Methodology}

This research has a qualitative focus, which intends to explore real life in a limited system through the collection of data, and multiple information sources (Cresswell, 2013). The methods were archive analysis, observation, and open interviews to the dwellers. The several publications from research projects performed in Agua Blanca allowed analyzing the conditions of the village from different perspectives, especially from tourism, and anthropological areas. Meanwhile, this information was verified, complemented and updated by the observational experience within the community and interviews to the dwellers. The target was to identify the dynamics of the place in a social, economic, and environmental dimension.

In order to describe the population, the criteria for the sample was to reach the opinions, attitudes, interests and motivations of dwellers with different roles and backgrounds within the community. On one hand, the leader of the community, the park guides and the current archeologist who are more involved in the collective activities. These interviews developed as personal (between the researcher and the interviewed) and group interviews (between the researcher and the group). On the other hand, the interviews to rest of the dwellers developed through visits house to house. The intention was to reach members from all the small settlements that conformed the community, considering the difference of population between the three of them (Table 1).

\begin{tabular}{|l|c|l|}
\hline \multicolumn{1}{|c|}{ Interviewees } & Number & \multicolumn{1}{|c|}{ Location } \\
\hline Dwellers & 28 families & $\begin{array}{l}14 \text { from the } \\
\text { Center, } 10 \text { from } \\
\text { El Carmen and } \\
4 \text { from Vueltas } \\
\text { Largas }\end{array}$ \\
\hline Park guides & 5 & $\begin{array}{l}\text { Community } \\
\text { Center }\end{array}$ \\
\hline $\begin{array}{l}\text { President of the } \\
\text { comittee }\end{array}$ & 1 & $\begin{array}{l}\text { Community } \\
\text { Center }\end{array}$ \\
\hline Researcher & 1 & $\begin{array}{l}\text { Community } \\
\text { Center }\end{array}$ \\
\hline
\end{tabular}

Table 1: Interviewees

Source: Author 
The obtained information was completed with fieldwork, observation notes, personal documents and photographs. As a descriptive data, the information that was taken from the interviews was encompassed to relate contemporary with historical attitudes and behavior of individuals or groups. The collected data captures the lived experiences of the social, economic and environmental world of Agua Blanca and how the people give meaning to these experiences from their own perspectives. Thanks to the relationship established between the interviewer and the informants, it was easy to develop a clear case of study protocol with a careful consideration and validity.

\section{The social dimension}

\subsection{A collective territory and a mechanism to regulate it}

The territory in Agua Blanca is entirely collective i.e., there is no private ownership of the territory. The community manages its resources for the collective wellbeing. A committee regulates both the land use and the productive activities by imposing a mechanism based on self-organization, whose fundamental principles are the equity in the access and the distribution of resources.

Ahorita están dando quince por veinte, para construir su casa quince por veinte, ese es el terreno que le da la comunidad acá y según lo que se vaya extender, por ejemplo, si quiere hace un huerto se puede extender un poco más y si quiere hace un corral para los animales también ${ }^{1}$. (Ventura, E., personal communication).

E. Ventura, a community member, specified that they have the right to use a land piece of $15 \times 20$ meters to build a house. This land can be extended if they wish to add a stockyard or an orchard according to the family's necessities.

The president of the commune, who is elected democratically leads the committee, and all the villagers are invited to attend monthly meetings that take place in the communitarian building. The committee heads assemblies that are spaces for reflection, experimentation, and building trust, and they are also a prominent space of local politics (Escalera \& Ruiz, 2011).

The natural resources of the territory can be used only by the community. All the villagers can acquire land for housing or any other economic activity within a domestic framework such as livestock or agriculture, only by asking the committee, which is responsible of deciding if the activity does not threaten the community i.e., discomfort to the environment or harm to the archeological remains. Any person outside the community cannot benefit economically from the local resources.

Moreover, there is a form of collective work-minga- that intends to maintain and build shared structures within their territory, such as roads, cemeteries, irrigation systems, among others.

\footnotetext{
${ }^{1}$ Right now they are giving fifteen by twenty, to build their house fifteen by twenty, that is the land that the community gives here and according to what is going to be extended, for example, if you want to make a garden you can extend it a little more and if you want to make
} a corral for the animals as well.

\subsection{Indigenous identity and diversity}

Smith (2015) recognizes that the Agua Blanca community has been attributed a miscegenation that prevents its inhabitants from being recognized as heirs of an authentic millenary culture. The reasons for this lack of recognition is because the native language and dress are still necessary proofs of true indigenism; those who have chosen to adopt another language or traditional costumes are considered outside the indigenous scene. However, the author points out that the abandonment is related to the risks involved in assuming indigenous identity, especially in areas where indigenous organizations are weak or absent, such as the Ecuadorian coast. In this context, tourism plays a vital role because it reinforces the indigenous as a subject shown and defended in the tourism arena.

Even though the villagers identify as part of a single group that shares a cultural bond, there is an internal diversity. According to Ruiz (2009), Agua Blanca bases on the nuclear family and the absence of closed kinship groups; which strengthens relations of friendship and neighborhood. Families share similar conditions in terms of the opportunities to exploit the environment nonetheless, the heterogeneity in the community lies in how any individual has responded with a diversity of strategies and results. For instance, the forest is a collective resource, some of them use it as resource to show it to the tourists, and others use part of it for agriculture or livestock. These responses have differentiated their economic income, which marks the small-scale social differences within the community.

\subsection{Alive heritage}

The archaeological assets are undoubtedly an essential part of the tangible heritage of Agua Blanca, and most of the projects - mainly directed by foreign professionals and organizations - have been executed to safe-guard them. Currently, archaeological projects continue. However, in this community, the heritage goes beyond the archaeological remains, encompassing the natural environment, ways of life, and traditional architecture that tries to adapt to contemporary reality.

Within this framework, Ruiz (2009), argues that the level of protection and conservation of a community's heritage remains in the importance and meaning of this heritage in the identity of the villagers. The significance of heritage within the community must have an effect that nourishes and enriches life, offering new dimensions or arguments for the relationship of each other. They have not built alien natures or dead cultures, but rather environments in which to live and cultures in which to recognize themselves. Therefore, there is a real cultural authenticity -an honest place- rather than an artificial tourist destination due to the presence of residents. They provide life to Agua Blanca through some everyday local activities that empower collectivity.

One of the main activities is washing clothes by hand at Buena Vista River. This activity involves the women from the community, who take advantage of this moment to socialize among themselves. They have even developed the ability to carry basins full of clothes on their heads. Neighbors, sisters, daughters, and friends walk 
together towards the river and help each other to finish washing their piles of clothes to return as a group. This practice is deep-rooted in the community. Years ago, the government tried to adapt a community concrete structure that was supposed to facilitate hand washing, but it was never used. It was a project that did not take into account the social meaning behind this activity.

Another particular social mechanism in Agua Blanca was the construction of houses for the young, detected by Smith (2015), who indicated that the villagers have the tradition of building small, single-room structures around the main house of a family that is open to the young ones for their independence. Besides, other young people did not have to return at night to their homes after their soccer matches, keeping them safe. However, this practice decreased. The function of these structures was also to store crops or household items. Today, some families have decided to build these structures as cabins for tourists.

The town also celebrates local holidays, that cultivate social and cultural ties. The main festivities are:

- The commemoration of the inscription the village as a parish that is celebrated with a mass and a program in the communal house every February 15th.

- The San Isidro Labrador festivities, characterized by the presence of pilgrimages, and various traditional shows to celebrate the association between water and San Isidro. It is customary to go on pilgrimage on May 15th to drink the water of the saint that springs up in the communal lagoon.

- The Balsa Manteña Festival takes place on October 12 th as a reminder of the ancestral maritime journey. It is a ceremony that takes place in the lagoon; some of the villagers wear typical costumes and perform on an ancient raft.

\section{The economic dimension}

\subsection{Articulation and complementarity of economic activities}

Ruiz (2009) conducted an in-depth study of the economic processes in the community; he recognized a very elastic and flexible economy, which makes it challenging to carry out a catalog of activities and evaluate their meanings in a closed manner. However, it points out some essential activities in the economy of some families of the commune. A total of 22 different productive activities were cataloged, the main ones are agriculture, livestock, tagua recollection, charcoal commerce, construction, public sector income, park ranger, local commerce, park guide, hand washing for externals.

The community-based tourism has been one of the keys to improving the economy of the village because it became a collective process. The community leading committee, referred in the social dimension, assures that most families have the chance to benefit from tourism not only as park guides (a job mostly occupied by men), but they provide spaces for artisans (mostly women) to sell their art crafts or offer rooms in their homes to host visitors. Besides, there is a communal restaurant where the villagers may work, and the profits are for the entire community. The collective work is also directed by other activities such as agriculture. Since the community counts on an irrigation system, which provides water at least for the crops around the center of the commune. Furthermore, there is a cost for the entry of tourists and products outside the community. Currently, the cost for admission is five dollars per visitor, and it is divided into eight items for the maintenance of communal locations. Therefore, the management of their economy supports their collective capacity for action and decision-making because it reinforces the indigenous (shown in tourist arena); it activates the community as a political agent; it fosters the development of new actors; and it promotes communitarian tasks for communication, action and collective decision making (Ruiz \& Hernández, 2010).

The economic activities are not closed to any group, but the members of the community perform them in a complementary and articulated way. That is to say, the domestic economy of the commune work as a whole, and tourism performs as a means that allows the desaturation of other activities based on the exploitation of resources. An example of this mechanism is the complementarity between the collection of tagua and park guiding (a tenday shift activity); which means that, during the days of work in the group of tour guides, these members could not collect tagua, relieving the pressure on the forest and facilitating the collection of the other companions. This kind of rotation is a way to guarantee equality of opportunities for the families and individuals.

As it was mentioned, there is small-scale social difference in the community due to the economic income, marked by the way that villagers exploit the available resources. This situation is perceived especially when comparing the economic income of families according to their location in different population centers of the town: the central nucleus (where the tourist attractions are located), El Carmen and Vueltas Largas (small settlements far from the center where villagers focus more on agricultural and farming activities). Ruiz (2009), detected a significant difference in the weight that economic activities have in each nucleus that distinguishes the monetary income in each family. Thus, there are two fundamental forms of dependence on the environment: the collection and exploitation of wild resources or as a resource that is shown to the visitors.

\subsection{Relationship with other territories}

The relationship of the villagers with the neighboring towns, especially Puerto López, is mainly for trade that is not possible inside the commune. Although, several vendors come to Agua Blanca to offer products, such as water, construction materials, amongst others. Furthermore, this dwelling has shown openness to visitors as researchers, volunteers, and internship students. The entrance for these visitors to the community is free, and the villagers have specific accommodations for them. The villagers admit that their presence enhance the community because they can show them new perspectives, and they can shed light on some aspects that need to be acknowledged. This is a lesson that they learned when McEwan and Silva -external people and researchers- helped then to retrieve their territory. 
It is important to reveal that the communitarian structure does not precisely conceive to work for the external but the internal individuals. The villagers do not count on entities that represent them in an external context. As a consequence, there is a lack of links to government organisms that may insert Agua Blanca in a macro framework.

\section{The environmental dimension}

Heritage is usually studied without considering the environmental context in which is inserted; in this study, the environmental variable is essential to understand the governance mechanism in the community since it lies in a natural protected area. The forest protection became a way of economic subsistence (because the main activities are based on tourism that requires forest conservation), and the means to protect the territory. The dry coastal forests of Latin America are considered in danger, and those located in Ecuador are within the ecosystems that represent a paramount crisis for the conservation of biodiversity in a worldwide perspective (Endere \& Zulaica, 2015). In this context, the commune's respect for the natural heritage is noteworthy, converting that respect into a way of life, becoming the guardians of the woods. Meanwhile, the struggle for territory and environmental protection merge as one: nobody better than the commune itself to observe environmental policy and surveillance of the territory; if they consider it theirs, they will assure its preservation (Ruiz, 2009).

Although at first, there was a rejection of the environmental conservation policies coming from the Machalilla Park delegates, the community itself gradually introduced environmental criteria and recommendations. For example, the timber trade has been almost completely eradicated, and the priority use of dead trees has been promoted. Likewise, the villagers are the ones who watch over the animals of the valley and not the environmental policies; thus, it is a model of environmental conservation, revealing itself against imposed models. This model developed through an internal process based on negotiation rather than imposition. Dwellers took a position where the relation to the natural habitat is from inside, as part of a whole, i.e., safeguarding the environment is safeguarding themselves. They rejected a usual position to preserve the environment, i.e., when communities transform the environment into an independent object from them Within, this context, caretaking the habitat becomes a sacrifice and the responsibility for the environment becomes fake and self-defeating (Ruiz, 2009).

\section{Discussion}

Heritage may improve the economic situation of a community; it should not be a means to benefit just a few people since heritage is a collective possession. The market undermines the communitarian link if it promotes individualism as the exclusive rule of participation (Ruiz \& Hernández, 2010). Therefore, participatory heritage management must guarantee that the economic rewards are distributed as equally as possible within a community. In Agua Blanca, the villagers have economic incomes from its natural and cultura heritage not only through direct participation in tourism but because this variable desaturated the competence from the rest of the activities. It is a mechanism of complementarity of economic activities (Ruiz, 2009). Moreover, the leaders are constantly promoting new communitarian spaces to benefit more members, such as the communitarian restaurant or the artisan's pavilion. If local members benefit from heritage, they protect it; otherwise preserving becomes a liability rather than a benefit (Chirikure et al., 2010). Nevertheless, most of the community improvements are focused on the central area of Agua Blanca, ignoring the further small settlements, Vueltas Largas and El Carmen, whose inhabitants feel neglected. Thus, the community has not reached a level of total inclusion of the community members.

El agua viene por manguera, de allá de la montaña, hay un pozo, viene por gravedad, solamente para los de aquí de Vueltas Largas, pero de acá no es ayudado por nadie, ahí no hay ayuda de nadie. No es que el gobierno lo haya mandado a hacer, nosotros mismo lo hicimos². (Tomalá, A., personal communication)

J. Tomalá when talking about the water implementation in the houses of his community, Vueltas Largas, expressed the lack of help of any entity during this process. In this context, the villagers need to develop a territorial plan that helps them to overcome this segregation through a better connectivity among settlements and a more compact town expansion in the future.

Heritage in any community needs a cultural significance for its members; in other words, its values and meanings need to be understood. This is possible through the introduction of heritage literacy which, according to Babic (2015), is a way that empowers people to use heritage in a way they consider most appropriate for their development and could ensure citizens to become managers of their heritage. The inhabitants in Agua Blanca, for instance, did not recognize the value of their archeological remains or biodiversity of their woods until experts helped them to change their perspectives for their welfare. The strategy of the experts was to involve the villagers in every stage as real partners; consequently, they created a new and evolving role in heritage management where the heritage practitioners also functioned as facilitators and synthesizers. The result is a change in the perceived authority of the heritage expert and more interest from the community to get involved in preserving heritage (Mackay, 2010). Today, the villagers keep welcoming researches and volunteers as a means to keep benefiting economically and intellectually from the feedback that experts and people from other backgrounds provide. It is important to emphasize that local residents are a priority, while experts and other social actors play a secondary role as facilitators ( $\mathrm{Li}$, Krishnamurthy, Pereira \& Van Wesemael, 2020).

However, as Wang \& Aoki (2019) illustrate, the dwellers heritage conservation awareness can be severely

${ }^{2}$ The water comes by hose, from over there on the mountain, there is a well, it comes by gravity, only for those here in Vueltas Largas, but from here it is not helped by anyone, there is no help from anyone. It's not that the government has ordered it to be done, we did it ourselves. 
repressed when confronted with their daily struggles and immediate interests. They may tend to favor heritage-harming solutions as efficient solutions to their immediate problems. In Agua Blanca, this situation is more visible within the housing construction scene since the local residents prefer to build their houses using materials that harm the natural and cultural landscape. The adoption of these materials is an easier and cheaper option for the dwellers that confront with their heritage preservation awareness.

Cuando le hice primerito era de cade y de ahí ya hubo un billetito y le puse zinc ${ }^{3}$ (Tomalá, A., comunicación personal).

Cambié a zinc porque el cade trae bichos y ratones ${ }^{4}$. (Merchán, P., personal communication).

Tomalá and P. Merchán, two dwellers, for instance, express the reasons behind the replacement of cade (a natural material) for zinc for their houses' roofs (a materia that disadvantages the interior thermal comfort and the landscape). It is inferred that it is important for them to worry less about maintenance and to show through the materials a better economic status. Nevertheless, they also keep a "native" atmosphere to show the tourists, so they choose to build with natural materials only the structures intended for touristic activities.

La losa de hormigón la puse desde el principio, solo el cuarto tiene tablones de madera para los turistas ${ }^{5}$. (Ventura, E., personal communication).

This last affirmation displays how this person chose concrete for his house flooring structure except the space destined for the tourists because tourists expect a different experience when they stay in the community. Al the communal touristic structures preserve local materia and forms. Thus, the authenticity of the community lies in the activities and decisions that they choose for themselves rather than what they do for external people to see.

A critical side of heritage is authenticity when considering a place like Agua Blanca, where heritage involves a set of tangible and intangible components, its authenticity is perceived mostly through the continuing presence of residents. As Mackay \& Johnston (2010) recognizes, in a heritage village named The Rocks (Australia), the residents are the ones that provide an outward visible sign that it is a living community, and through their presence, provide a connection between past, present, and future. This is also what happens in Agua Blanca, the everyday activities of its inhabitants as animal farming or hand washing have become part of an authentic cultural landscape. It is not about preserving heritage for postcard pictures but keeping the dynamics alive, which also need to frame into contemporary world demands.

The inhabitant's traditional practices are enough for the audience to imply that this is an indigenous community yet, but their life-style is threated by contemporary items (motorcycles, television, phones); however, these perceptions belong to an external colonized

${ }^{3}$ When I first made it, it was made of "cade" (palm leaf) and from there, there was already a little "billetito" (money income) and I put zinc on it.

${ }^{4}$ I switched to zinc because the "cade" (palm leaf) brings bugs and mice.

${ }^{5}$ I put the concrete slab in from the beginning. Only the room has wooden planks for the tourists. perspective, their own nostalgic desire to preserve the decontaminated by contemporary culture (Smith, 2015). In the heritage scenario, as many authors recognize, it is essential to overcome a legacy of scientific colonialism and respect the alternative ways of interpreting and knowing the past (Hollowell \& Nicholas, 2009), especially from the heritage heirs. In Agua Blanca, the locals are engaging directly with their audiences to reinforce their authenticity and own meaning of their culture; they try to tie a traditional organization with a globalized activity, the tourism. Agua Blanca shows that community is a collective expression that should be considered as an innovation for the organization of a dwelling rather than the ancestral spirit of a population (Ruiz, 2009).

In terms of the mechanism for participatory governance, in Agua Blanca, the collective action is guided by an assembly strategy and a rotational logic that aims to reach equality within its society (Ruiz, 2009). The committee plays an essential role because it is the means that keeps a constant cohesion of the individuals to debate and to take action. The villagers are capable to expressing their necessities and unconformities, treated with the right amount of flexibility and rigidity, essentially in the quest for the collective welfare. Comparing this governance system to other similar cases, it was found the "Chillan" community in Chile that is regulated by the Unidad de Patrimonio de la Municipalidad de Chillan; according to Escalera \& Guerrero (2019), they keep a regulatory framework of citizen participation based on orientation rather than imposition. This principle has resulted efficient in both villages since heritage is not perceived as a burden but an advantage.

Unfortunately, there is also a lack of interest from young people in the community to attend the committee meetings; young people are still not fully aware of the struggle for the territory and the history of the community, endangering the future of Agua Blanca. The villagers require to envision a plan capable of empowering the new generations that have grown in a different context; therefore, have different necessities and perceptions. The committee should encourage the young to work on projects that implement technological systems capable of improving the sustainability of the community. Moreover, systems that enhance the community media management which today is poor Besides, the young could be part of cultural exchange programs that provide them a bigger perspective of the world and their own culture. These programs would also be an opportunity to develop the villagers' language skills since the lack of bilingual villagers has become a barrier in the tourism arena.

Regarding the obstacles of the community, Agua Blanca faces a dissociation between national organisms, which impedes a multi-level development that would facilitate internal processes that need more financial support. The villagers should establish a committee in charge of external relations since their current committee is mostly focused on internal processes. Meanwhile, the government can also take advantage from a positive participation in the heritage management of Agua Blanca. This cooperation may allow the state to make use of cultural traditions and resources to strengthen national economies, construct official narratives of 
history, monitor minorities, and contain local discontent (Chan \& Lee, 2017).

Finally, it is interesting that a community that is so close to a coastal environment is so little related to the maritime world. The only remains are the Balsa Manteña Festival where the dwellers build a model of a native maritime raft to cross the small communal lagoon. When there was a dispute over the territory between community members and the Machalilla National Park authorities, it was only possible to recover the current territory that does not include any beach as such. Currently, only some elderly people regret not having included a part of the sea in their official territory. Sadly, many communities have experienced the loss of important territories. Agua Blanca is an example of how the dwellers adapt to their current resources and attach to them to give them more significance, in this case, the archeological remains and the forest.

\section{Conclusions}

Current dynamics in Agua Blanca lead to sustainable heritage management since the environmental, social, and economical procedures are developed for a collective benefit. These dynamics are a consequence of challenging processes that are continuously evolving. Therefore, the governance mechanisms should be aware that this community is not a stable and permanent system, they have a set of obstacles that have been overcome through self-organization. The lessons taken from the relationship of this community with its heritage may help to shed light to other communities, especially in Ecuador and Latin America, as long as they are framed into their particular variables. For instance, in Agua Blanca, tourism worked as a means to protect heritage; however, this is not always the case; in other contexts, tourism may even represent a threat to heritage. Decision-making should be based on a deep understanding and critical reflection of the place and the inhabitant's perceptions and needs. It is crucial a participative heritage management that involves diverse stakeholders, researchers, government organisms, and any other implicated part. Moreover, spaces for reflection about the governance structure should be promoted to guarantee its effectiveness and sustainability, and redefine it if necessary.

\section{Acknowledgments}

María José Castro Castro, member of the research team. Fausto Cardoso Martínez, research advisor. Agua Blanca community.

Cómo citar este artículo/How to cite this article: Juca Freire, N. (2021). Governance of heritage. Challenges of a community strengthen by its heritage. Estoa. Revista de la Facultad de Arquitectura y Urbanismo de la Universidad de Cuenca, 10(19), 45-53. doi: 10.18537/est.v010.n019.a04

\section{Bibliographic references}

Babić, D. (2015). Social Responsible Heritage Management - Empowering Citizens to Act as Heritage Managers. Procedia Social and Behavioral Sciences, 188, 27-34. https://doi.org/10.1016/j.sbspro.2015.03.335

Chan, Y. W. \& Lee, V. P. Y. (2017). Post-colonial cultural governance: a study of heritage management in post1997 Hong Kong. International Journal of Heritage Studies, 23(3), 275-287. https://doi.org/10.1080/13527 258.2016.1269238

Chirikure, S., Manyanga, M., Ndoro, W. \& Pwiti, G. (2010). Unfulfilled promises? Heritage management and community participation at some of Africa's cultural heritage sites. International Journal of Heritage Studies, 16(1-2), 30-44. https://doi. org/10.1080/13527250903441739

Creswell, J. W. (2013). Qualitative inquiry and research design: Choosing among five approaches. Sage

Endere, M. L. \& Zulaica, M. L. (2015). Socio-Cultural Sustainability and "Buen Vivir" (Good Living) at Heritage Sites: Assessment of The Agua Blanca Case, Ecuador. Ambiente \& Sociedades, 18(4), 265-290.

Escalera, R. J. \& Guerrero, V. R. (2019). Conflictos y oportunidades de la participación ciudadana en procesos de patrimonialización local: estudio de casos en España y Chile. Apuntes, 32(2), 2-16. https://doi.org/10.11144/ Javeriana.apc32-2.copc

Escalera, R. J. \& Ruiz B. E. (2011). ResilienciaSocioecológica: aportaciones y retos desde la Antropología. Revista de Antropología Social, 20(0). https://doi.org/10.5209/rev_ RASO.2011.v20.36264

Hollowell, J. \& Nicholas, G. (2009). Using Ethnographic Methods to Articulate CommunityBased Conceptions of Cultural Heritage Management. Public Archaeology, 8(2-3), 141-160. https://doi. org/10.1179/175355309X457196

Li, J., Krishnamurthy, S., Pereira Roders, A. \& van Wesemael, P. (2020). Community participation in cultural heritage management: A systematic literature review comparing Chinese and international practices. Cities, 96 , 102476. https://doi.org/10.1016/j.cities.2019.102476

Mackay, R. \& Johnston, C. (2010). Heritage Management and Community Connections on The Rocks. Journal of Architectural Conservation, 16(1), 55-74. https://doi.org /10.1080/13556207.2010.10785062

McEwan, C., Silva, M. I. \& Hudson, C. (2006). Using the past to forge the future: the genesis of the community site museum at Agua Blanca, Ecuador. Silverman, H. (Ed.), Archaeological site museums in Latin America (pp. 187216). University Press of Florida

Ruiz, B. E. (2009). Agua Blanca: Comunidad y turismo en el Pacífico ecuatorial. AbyaYala. 
Ruiz, B. E. \& Hernández, R. M. (2010). Tourism that empowers? Commodification and appropriation in Ecuador's turismo comunitario. Critique of Anthropology, 30(2), 201-229.

Smith, K. (2015). Practically Invisible: Coastal Ecuador, Tourism, and the Politics of Authenticity. Vanderbilt University Press

Wang, X. \& Nobou, A. (2019). Paradox between neoliberal urban redevelopment, heritage conservation, and community needs: Case study of a historic neighborhood in Tianjin, China. Cities, 85, 156-169. https://doi. org/10.1016/j.cities.2018.09.004 